\title{
Hedging As a Rhetorical Strategy in Political Discourse
}

Received: February 03, 2018

doi: $10.30587 /$ jetlal.v3i1.788

\author{
Fenty Andriani \\ Institut Agama Islam Negeri Ponorogo \\ fentyandriani@iainponorogo.ac.id
}

Accepted: February 15, 2019

Published: February 27, 2019

\begin{abstract}
This study aims at investigating and analyzing two aspects of hedging in the first English spoken political action: (1) types of the devices, and (2) the reasons behind uttering them. The corpus providing the database for the study is Barrack Obama's first televised interviews after being inaugurated as the president. Selecting him is absolutely for considering that he is the best representative to represent the other native politicians in spoken discourse. The questions and comments in the interviews were centered on the interviewee's position. A body of 130 sentences from the first interview and 136 sentences from the second one were got for a detailed analysis as the data. For the goals, they were described qualitatively with the so-called 'intertextuality' as the assistant to get the valid and reliable findings. Findings have shown that: (i) numerous means of hedging produce numerous pragmatic functions, (ii) conversational and discourse strategies including Grice's maxim's are rarely adhered to in spoken political discourse, (iii) hedging is able to stem from the inner conflict between intention and desire, and (iv) As a president, Obama hardly produces a sentence that is free of all kinds of indirectness, indetermination, approximation or vagueness.
\end{abstract}

Keywords: Hedging, Pragmatic Functions, Political Discourse

\section{Introduction}

Politics is an effort for power in order to put certain political, economic and social ideas into practice. For politicians, language, thus, is always a powerful tool to lose or to win. This is, however, a very clear fact that makes them think twice before answering questions as they want to protect themselves against any future possible criticism if proved wrong later on (Taweel et al., 2011: 175). In this process, no wonder, if their first political actions, specifically the first presidential-media interviews, are delicately prepared and accompanied by hedging devices.

The term hedging is now used to cover a number of interrelated concepts, namely indetermination, vagueness, indirectness and approximation (Zuck \& Zuck, 1986; Brown \& Levinson, 1987; Hyland, 1998; Btoosh, 1999; Btoosh, 2004; Varttala, 2001; Vass, 2004; Chavez; 2004; Ayodobo, 2007; Vazques \& Giner, 2008; Donesch-Jezo, 2010; see Taweel et al., 2011: 171). In a more comprehensive account of the term, hedging is associated with all terms or expressions leading lack of full commitment (Fraser, 2010: 201).

Hedging is a rhetorical strategy. By uttering a term or perhaps choosing a certain structure, the speaker shows a lack of a full commitment either to the full category membership of an expression in the utterance or to the intended illocutionary force of the utterance (Taweel et al., 2011: 171).

By using hedging devices, speakers are able to indicate a lack of commitment to the truth of the proposition and not to express the commitment categorically. Realizing the important roles of hedging devices in communication and their unique pragmatic functions, unfortunately, it is found that little study has been conducted concerning on them in political discourse. An unfortunate fact that has presented a serious challenge for the researcher to investigate the hedging devices used by the politician.

As a matter of fact, in addition, since hedging is a rhetorical strategy with all of its unique pragmatic functions and its devices are context-dependent devices (Lakoff, 1973: 484), there are absolutely certain reasons for selecting them in the first political actions. This study, thus, intends to also concern on them. 
Given the enormous politicians, it is crucial to carefully investigate the selected hedging devices uttered by one of the English native speaker politicians to be the subject of this study. Barrack Hussein Obama was chosen as the subject of the data since he has a very incredible public speaking skill. As the $44^{\text {th }}$ U.S president, Barrack Obama ran for president on a ticket promising change and came to the white house with high expectations from his supporters. Selecting Barrack Obama as the main subject is absolutely not without any other reasons.

It is known that the United States of America was one of the first republics of the modern era, and to this day possesses one of the world's longest-lasting political regimes. No wonder if political leadership in this country been stable over the years. Once a president is elected, it is almost impossible to get rid of him until the following election. Then, because Obama is the very special first-black president of this world's foremost economic and military power country in an historic election, so, it is believed that by selecting his first media live-broadcasted interviews, this study can be one of the most useful and enduring insights to come out of the recent study of language use for investigating the way a politician applies hedging.

Another crucial reason for selecting Barrack Obama also deals with the fact that hedging is affected by gender: women's speech lacks authority. Lakoff (1972:90) states that women prefer uttering unassertive style of communication to the assertive one. That is, they must learn to eliminate their statements of declarative force (p. 174). No wonder, thus, studying how and why a man politician applies hedging in his first political action is much preferred than a woman.

Up to this point, involving mass media, specifically the live-broadcasted interview on TV, has something to do with political discourse. Realizing that politicians are not the only participants in the domain of political discourse, the various recipients in political communicative events, such as the public and the 'mass media' are also crucial to be included (Atkinson \&Heritage, 1984; Boden \& Zimmennan, 1991; Van Dijk, 1985; Van Dijk, 1997: 20).

The other major point in this argument is that such an analysis of political discourse should not merely be a contribution to discourse studies but also to political science (Van Dijk, 1997: 11). This means that PDA should be able to deal with issues that are discussed in political science. What the linguists and scholars find in political science are studies on political communication and rhetoric (Bitzer, 1981; Swanson \& Nimmo, 1990; Van Dijk, 1997: 12). This fact, therefore, is another crucial reason for getting Barrack Obama's first presidential interview investigated via hedging.

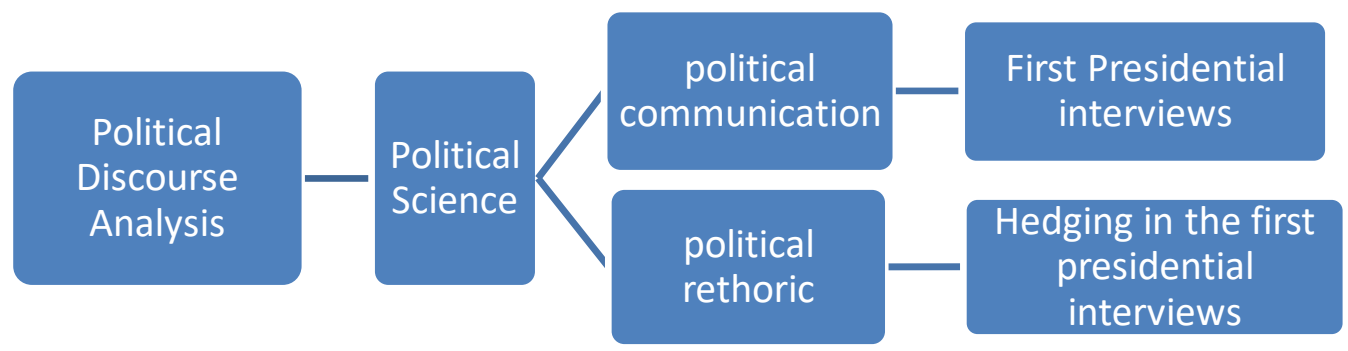

Figure 1: The Political Science Issues of the Research (Van Dijk, 1997)

Hedging is very crucial for politicians, as stated by Taweel et al. after conducting a research on "Hedging in Political Discourse" in 2011. The data of the study consists of seventeen randomly selected televised interviews with a number of Arab politicians and leaders during the third Gulf War, the Desert Fox. The questions and comments in all the interviews were centered on the interviewees' positions from the war and the proposed solutions. A body of 13, 168 words was selected for a detailed analysis. However, due to the Arab hedging devices, it is absolutely wondering the readers to know how and why hedging in English spoken political interviews applied. Moreover, though the pragmatic functions of this previous study have been described well qualitatively, since other facts or texts to strengthen the arguments were not touched, subjectivity is strongly felt by the readers. Although the interpretation of a text is never totally objective and the researcher's interpretation affects the message positively or negatively depending on his/her own understanding of the issue, it is still a must for the researcher to make his/her study less subjective. 
This fact, therefore, has encouraged this study's researcher to refer to other texts (intertextuality) for not only getting her interpretation less subjective but also more valid. In other words, intertextuality was used as one of the most important aspects to interpret the data.

This study, thus, treated hedges as context dependant means and that there is no limit to the linguistic expressions that can be considered as hedges. In other words, almost any linguistic item or expression in this study was interpreted as a hedge depending on the communicative context.

Overall, a study of hedging in Barrack Obama's first presidential interviews (2009 and 2012) has been conducted to investigate the kinds of hedging devices used and the reasons for selecting them. The formulation of the research questions are:

1. What are the types of hedging devices used by Barrack Obama in his first presidential interviews (2009 and 2012)?

2. Why does Barrack Obama apply hedging in his first presidential interviews (2009 and 2012)?

a. What are the strategies employed to serve hedging?

b. What are the pragmatic functions of hedging devices uttered?

\section{Method}

In conducting this study, the researcher used descriptive qualitative as the research design. Here, the researcher applied qualitative research as it can give the readers sufficient details of how and why hedging is always a powerful tool used by a politician in his first political action. In a more comprehensive sentence, qualitative research was used to add rich detail and nuance that illustrates or documents existing knowledge of Barrack Obama's hedging in his first presidential interviews. Thus, by having this qualitative research, the hedging perspective of a political discourse that is not well understood because of the narrow perspectives used before could be widen. Besides, a political phenomenon is difficult or impossible to approach or to capture quantitatively

The data were the utterances of Barrack Obama in his first presidential interviews after being inaugurated as the $44^{\text {th }}$ U.S president.

Sources:

1. The first presidential interview in the first presidency term was shown in Dubai AlArabia TV interviewed by Hisham Melhem in 17 minutes 29 seconds on January 27, 2009.

2. The first presidential interview in the second presidency term was shown in Bloomberg TV interviewed by Juliana Goldmannin in 19 minutes on December 4, 2012.

Findings

This first part is presented to analyze and discuss hedging devices types in President Obama's first presidential interviews. As a starting point, it seems acute to reconsider that not all of the president's statements express attitudes and feelings can be used for hedging. As has been declared in the previous paragraphs, what this study conducts deals with epistemic means that convey the speaker's complete commitment in the truth of a statement.

Secondly, hedging is mainly manifested into two major classes namely Approximators and Shields. Approximators refer to hedging devices that affect the truth condition of the statement and may change the meaning of the statement. They are further classified into Adaptors and Rounders. While Adaptors can be regarded as modifier, Rounders indicate the inexact case. Unlike Approximators, Shields refer to hedging devices that do not affect the truth condition but reflect the degree of speakers' convictions to the truth of the statement. They are divided into Plausibility Shields and Attribution Shields. Plausibility shields are used to show speakers' own attitude towards a statement. Then, Attribution Shields attribute the speaker's degree of uncertainty.

\section{Types of Hedging Devices in Obama's First Presidential Interviews}

The data would cover the first presidential interviews of Obama after being inaugurated as the $44^{\text {th }}$ U.S president in the first and second presidency terms. The first one was his first presidential interview in January 27 , 2009 interviewed by Hisham Melhem. The second one was his first presidential interview in December 4, 2012 interviewed by Juliana Goldman. Given 130 sentences from the first data and 136 sentences from the second one. This study would only focus on the president's sentences (the politician's utterances). The types of hedging devices in president Obama's first presidential interviews are listed in the following table: 
Table (1): Listing Types of Hedging Devices

\begin{tabular}{|c|c|c|c|c|c|c|}
\hline \multirow[t]{2}{*}{ No } & \multirow[t]{2}{*}{ Types } & \multirow[t]{2}{*}{ Subclasses } & \multirow[t]{2}{*}{ Members } & \multicolumn{2}{|c|}{ Data } & \multirow[t]{2}{*}{ Total } \\
\hline & & & & 1 & 2 & \\
\hline \multirow[t]{36}{*}{1} & \multirow[t]{36}{*}{ Shields } & \multirow{18}{*}{$\begin{array}{l}\text { a. Plausibility } \\
\text { Shields }\end{array}$} & I think & 21 & 13 & 34 \\
\hline & & & I don't think & & 1 & 1 \\
\hline & & & I believe & 3 & 1 & 4 \\
\hline & & & $\begin{array}{l}\text { I don't want to } \\
\text { prejudge }\end{array}$ & 1 & & 1 \\
\hline & & & I'm absolutely certain & 1 & & 1 \\
\hline & & & I might not agree & 1 & & 1 \\
\hline & & & Maybe & 1 & & 1 \\
\hline & & & May & 1 & & 1 \\
\hline & & & For me & 1 & & 1 \\
\hline & & & $\begin{array}{l}\text { There's possibility/ } \\
\text { probably }\end{array}$ & 1 & 4 & 5 \\
\hline & & & Question & 1 & 2 & 3 \\
\hline & & & I don't expect & & 1 & 1 \\
\hline & & & I've suggested & & 2 & 2 \\
\hline & & & I recognize & & 2 & 2 \\
\hline & & & I hope & & 1 & 1 \\
\hline & & & I don't really & & 1 & 1 \\
\hline & & & I'm really confident & & 1 & 1 \\
\hline & & & Total & 32 & 29 & 61 \\
\hline & & \multirow{18}{*}{$\begin{array}{l}\text { b.Attribution } \\
\text { Shields }\end{array}$} & We don't always know & 1 & & 1 \\
\hline & & & From there & 1 & & 1 \\
\hline & & & $\begin{array}{l}\text { We think/ For us to } \\
\text { think }\end{array}$ & 2 & & 2 \\
\hline & & & If we & 4 & 10 & 14 \\
\hline & & & We might & 1 & & 1 \\
\hline & & & $\begin{array}{l}\text { Hillary Clinton has } \\
\text { expressed this in her } \\
\text { confirmation }\end{array}$ & 1 & & 1 \\
\hline & & & If it & 3 & & 3 \\
\hline & & & It's possible for us & 1 & & 1 \\
\hline & & & $\begin{array}{l}\text { Anybody who has } \\
\text { studied the region }\end{array}$ & 1 & & 1 \\
\hline & & & They simply think & 1 & & 1 \\
\hline & & & What that tells me & 1 & & 1 \\
\hline & & & If you- If they & 1 & 6 & 7 \\
\hline & & & As you say & 1 & & 1 \\
\hline & & & $\begin{array}{l}\text { Some Muslim leader } \\
\text { may }\end{array}$ & 1 & & 1 \\
\hline & & & People who may & 2 & & 1 \\
\hline & & & You know & $\mathbf{1}$ & 25 & 26 \\
\hline & & & It could potentially & 1 & & 1 \\
\hline & & & They seem & 1 & & 1 \\
\hline
\end{tabular}




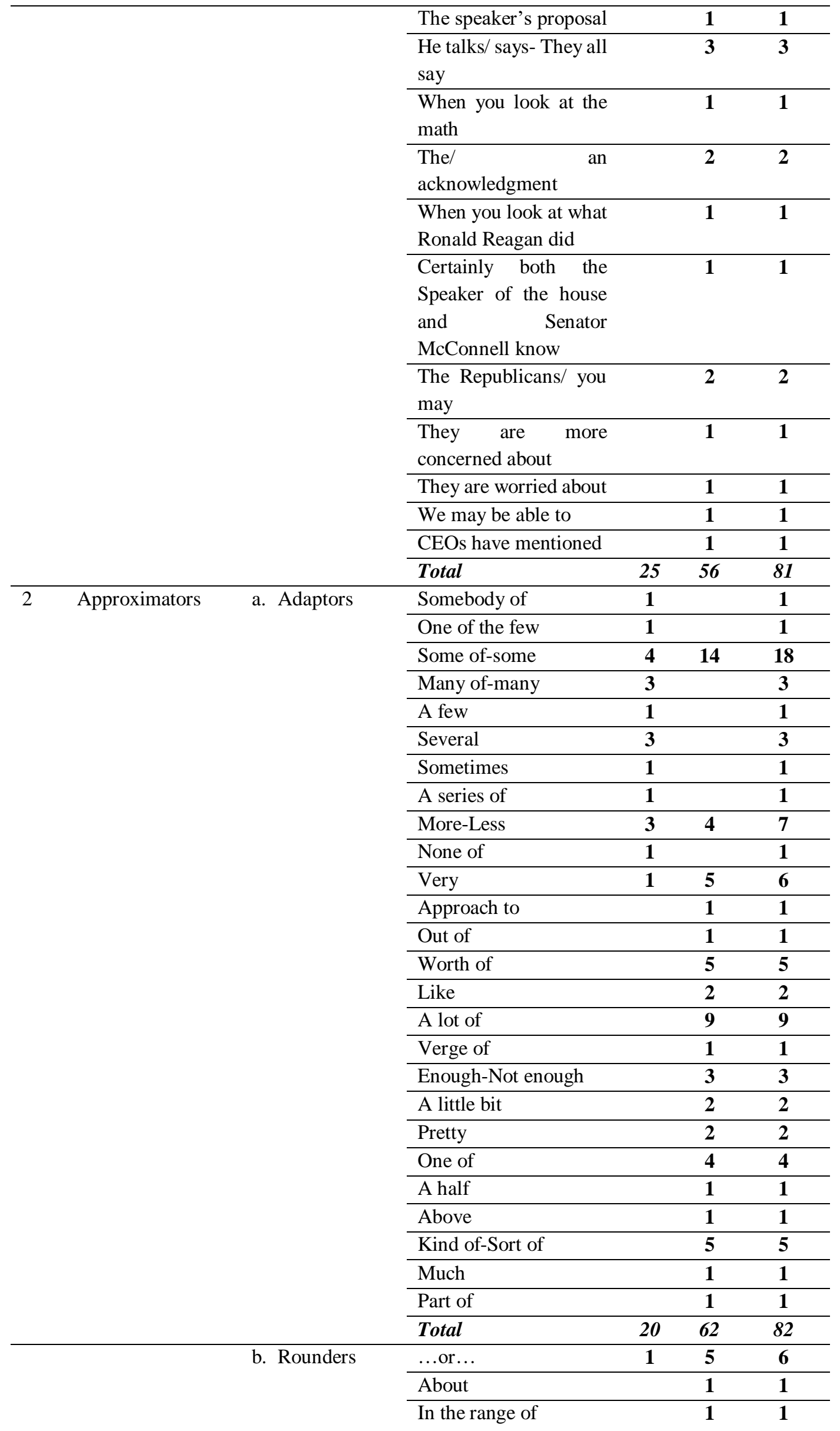




\begin{tabular}{|c|c|c|}
\hline Essentially & 1 & $\mathbf{1}$ \\
\hline A whole range of & 1 & 1 \\
\hline Around & 1 & 1 \\
\hline Total & 10 & 11 \\
\hline
\end{tabular}

Finding the types of hedging devices used by Barrack Obama in his first presidential interviews, it is the time to clarify and discuss some of their interesting facts. First of all, let the researcher discuss Shields, specifically the Plausibility ones. From 61 plausibility shields uttered, "I think" was the most dominant hedging device uttered by the president. Specifically, it was uttered more frequently in the first interview (Data 1) than the second one (Data 2) .The president uttered this device 21 times in the first interview, and 14 times (including "I don't think") in the second one. It is safe to say that the president's degree of doubtful in the second term first presidential interview was less decreased.

Unlike Plausibility Shields, which were more frequently used in the first term-first presidential interview, Attribution Shields were more frequently uttered in the second one. From 81 Attribution Shields, 56 of them were uttered in second interview (Data 2). A closer look at the president's choice of words, "You know" and "If we" were the most favorite devices uttered by the president. 25 items for "You know" and 10 items for "If we". They do clarify that, in the second presidency term, in answering the questions, President Obama preferred filling the pause via uttering the Attribution Shields of "You know" to showing his doubtful via Plausibility ones. Whether or not it is only a matter of an introductory phrase to fill the sentence pause, we are going to discuss it in the second part.

Then, in discussing the first subclass of Approximators, Adaptors, "Some"-"Some of" were the most dominant hedging device used both in the first and second interview. This fact shows the president's uncertainty to suit with non-prototypical conditions. To put it more specific, it can be clarified that, no matter what the questions were (politic or economic), the president had more intention to measure or judge a proposition via getting its class membership in a partial correctness, as in:

And I think that what you will see over the next several years is that I'm not going to agree with everything that some Muslim leader may say, or what's on a television station in the Arab world. They were uttered 14 times in the second interview and 4 times in the first one ...;

I recognize that, in the first four years, my relationship with the business community sometimes was skewed, because we're trying to do some tough things like health care reform and most particularly around welfare - Wall Street reform and - and Dodd-Frank... .

However, the researcher does not want to prejudge that it is a formula, just that looking at the other interviews (excluding the two interviews being analyzed), he likes measuring or judging a proposition in a partial correctness. It does clarify that politicians, specifically president Obama as the best representative, are hard to say a definite proposition if the exact data is unavailable or if they are sure that their receivers will not find any difficulty in finding the meaning. What the researcher wants to say is that even the speaker, let's go back to president Obama's interviews, did not know the exact Muslim leaders or the exact tough things, the receivers (the interviewer, the listeners, the audience) as a matter of fact did not find problem to catch the meaning. Then, that there was only 1 Rounder, “...or...", uttered in the first interview as in:

But if you look at the track record, as you say, America was not born as a colonial power, and that the same respect and partnership that America had with the Muslim world as recently as 20 or 30 years ago, there's no reason why we can't restore that. (See Appendix 1, Code: D1S88-Ro1).

and that there were 10 Rounders uttered in the second interview, which was dominated by “...or..." as well, as in the following one, were also the other interesting facts about Approximators to be discussed:

And then let's set up a process with a time certain, at the end of 2013 or the fall of 2013, where we work on tax reform, we loop at what loopholes and deductions both Democrats and Republicans are willing to close, and it's possible that we may be able to lower rates by broadening the base at that point. (See Appendix 2, Code: D2S64-Ro5). 
It seems safe to say that limiting the choice of items to convey a range of the unavailable exact data was his other way to ease the receivers catching the meaning and to solve his problem for not knowing the exact data.

Comparing the first interview to the second one, no wonder if Adaptors and Rounders were more frequently uttered in the second interview than in the first one due to the economic topic. This is the very clear plausible reason for them to work in tandem with economic cases specifically to convey a range.

In short, considering the "Middle East" (politic) and "Fiscal Cliff" (economic) topics in both interviews, a red line can be drawn: the interviewee is not a truth teller for considering the various epistemic items uttered to serve hedging. He hardly produces a sentence that is free of all kinds of indirectness, indetermination, approximation or vagueness.

\section{The Reasons Behind Hedging}

In this section, the researcher finds and discusses the reasons for selecting a certain hedging device in Obama's first presidential interviews after being inaugurated as the $44^{\text {th }}$ U.S president in 2009 and 2012. In working with this second part, for the purpose of this study, the researcher firstly formulated eight strategies employed to serve hedging. They were successfully formulated absolutely due to the preliminary analysis conducted. Those strategies employed to serve hedging are: Avoidance Strategy and Introductory phrases, Likelihood Modalities, Adverbs/ Adjectives, Sender-Receiver Solidarity, Hypothetical device, Epistemic Devices, Impersonal Attribution and Questions.

\section{a. Avoidance Strategy and Introductory Phrase}

As a starting point, comparing the overall questions to its answers, both the interviewer and interviewee have different strategies. The interviewer, on the one hand, mostly attempted to have a well-organized turn-talking model by limiting the options in front of the interviewee (yes/no questions). The interviewee, on the other hand, tried to almost always avoid direct answers by following the avoidance strategy as in:

Hisham ( $\mathbf{1}^{\text {st }}$ Interviewer): ... Will you be proposing ideas, pitching proposals, parameters, as one of your predecessors did? ...

President Obama: Well, I think the most important thing is for the United States to get engaged right away ...

Goldman ( $2^{\text {nd }}$ Interviewer): ... When are you going to come back with a new offer?

President Obama: Well, I think that, you know, we have the potential of getting a deal done, but it's going to require what I talked about during the campaign, which is a balanced, responsible approach to deficit reduction that can help give businesses certainty and make sure that the country grows ...

This, however, has led to the violation of the 'Conditionally Relevant principle, which forms the heart of the adjacency pairs. As a result of this, the interviewee's utterances were followed by an unexpected question from the interviewer.

The above first examples indicate that the interviewee flouted the maxim of quantity by saying more than what is required. He purposely resorted to provide more information than is required to avoid the yes/no answer. This indicates that he disfavors direct answers. The rest parts of the answer also flout the maxim of relevance by providing a statement that has no relationship to the question

Mostly, in flouting the maxims of quantity and relevance, the interviewee also realized the maxim of quality by uttering the empathetic introductory phrases such as "Well, I think" and "You know". To investigate the reasons behind uttering them, the three following examples are declared.

In uttering "I think", as exemplified in the first following example, toward the moribund IsraeliPalestinian peace negotiations, the interviewee actually serves a political aim: distancing his administration's policies from those of the previous one:

Hisham: Will you be proposing ideas, pitching proposals, parameters, as one of your predecessors did? 
President Obama: Well, I think the most important thing is for the United States to get engaged right away .

The main reason behind uttering the hedging device of "I think", in this context, has something to do with modifying ideas that is different with his predecessor, president Bush. Although semantically it seems that he intended to only propose his opinion rather than just a fact, by looking at the overall context it is more than just an opinion. He tried to mitigate his claim, politeness, so, is one of many possible effects achieved.

\section{b. Likelihood Modalities}

Touching "maybe" as the likelihood modality above, let's reveal it in deeper analysis by analyzing the following example:

I think it is possible for us to see a Palestinian state -- I'm not going to put a time frame on it -- that is contiguous, that allows freedom of movement for its people, that allows for trade with other countries, that allows the creation of businesses and commerce so that people have a better life...

Despite the Attribution Shield type and sender-receiver solidarity strategy, the researcher also included the likelihood modality strategy for "it is possible us". However, the researcher would argue that the entire question-answer to give the entire context of this exchange,

Consequently, uttering the hedging device of "It is possible for us", in this context, on one hand, is helpful to decrease the possibility of being criticized as he showing the receiver a degree of uncertainty has about the proposition. On the other hand, unfortunately, the use of "for us" might be unintentionally claimed as impolite, despite his intention to show politeness (sender-receiver solidarity of "us"), due to mitigating other speakers through inappropriate fact.

\section{c. Adverbs/ adjectives}

In discussing adverbs/adjectives strategy, as has been shortly discussed above, the researcher clarifies the other examples below:

And so what I told him is start by listening, because all too often the United States starts by dictating -in the past on some of these issues --and we don't always know all the factors that are involved...

You know, he talks, for example, about $\$ 800$ billion worth of revenues, but he says he's going to do that by lowering rates...

Despite the numerous devices attributed to adverbs/ adjectives strategy for hedging, a red line can be drawn. All of them were uttered to request the receivers' involvement, though the definite nominal is not mentioned, as the receivers will not find any difficulty to catch the intended meanings.

\section{d. Sender-Receiver Solidarity and Hypothetical Device}

Sender-Receiver Solidarity (we) and hypothetical device (if) are fused into one analysis for considering that "if we" was the most frequently hedges uttered after "you know", as in:

But if we start the steady progress on these issues, I'm absolutely confident that the United States -working in tandem with the European Union, with Russia, with all the Arab states in the region -- I'm absolutely certain that we can make significant progress ...

The main reason behind uttering "if we", in this context, at that time got deal with the president's struggle to protect himself against any possible criticism if proved wrong later on. Without attempting to judge him, just that even after knowing the opposite fact, the receivers, including the researcher, are consequently hard to blame him for considering that the proposition might be also interpreted as an opinion rather than a fact due to the hedging devices.

\section{e. Epistemic Modalities}


The following epistemic modality, as the example, was actually used to accompany the avoidance strategy,

Well, here's what I think is important; I might not agree with every aspect of the proposal, but it took great courage...

By uttering "I might not", the interviewee wanted to show his estimation of the validity of propositional content. He expressed his uncertainty to disagree (might not agree/ almost agree) with his hypothetical state of affairs about every aspect of King Abdullah proposal and also his lowest certainty about the peace that can be pursued (the peace is hard pursued). The pragmatic function of "I might not agree" in "I might not agree with the proposal, but they take courage", in this context, deals with the president's struggle for protecting himself against any future possible criticism. Besides, it was uttered for mitigating his claim about the proposal.

\section{f. Impersonal Attribution}

A different phenomenon is found toward impersonal attribution strategy, as in:

I think Hillary Clinton has expressed this in her confirmation, is that if we are looking at the region as a whole and communicating a message to the Arab world and the Muslim world, that we are ready to initiate a new partnership based on mutual respect and mutual interest, then I think that we can make significant progress

Although the above device seems used to only strengthen the interviewee's argument, it is actually used to also soften a criticism. He is not expressing hope, but rather he is criticizing the confirmation process in the first term that went in unexpected way. Drawing on the difference between the semantic or literal meaning and the pragmatic meaning, it seems that we are rapidly approaching the importance fact that different receivers may sometimes interpret one and the same text differently. This conveys that the interpretation of a text is never totally objective. As a result of this, the interviewer's interpretation affects the message positively or negatively depending on his/her own understanding of the issue.

\section{g. Question}

The last phenomenon is attributed for Question strategy to serve hedging as in:

And the bottom line in all these talks and all these conversations is, is a child in the Palestinian Territories going to be better off? Do they have a future for themselves? And is the child in Israel going to feel confident about his or her safety and security?....

Despite the question, the crucial point, in this context, is actually the indetermination and the mitigated message expressed. The question is used not only to hedge what is stated but also to draw the interviewer's attention to the real condition directly. The interviewee was not actually looking for information for his answer but rather he was actually trying to remind the public to the situation. The question strategy was not only uttered to indicate that a non-seeking information question is employed to attract the receiver's attention to a situation.

\section{Discussion}

There are two main types of hedges used in Barrack Obama's first presidential interviews (2009 and 2012) namely Shields and Approximators. This finding deals with Fraser's statement that hedging is mainly manifested into Shields and Approximators. Shields refer to hedging devices that do not affect the truth condition but reflect the degree of speakers' commitments to the truth value of the whole proposition. They are manifested into Plausibility Shields and Attribution Shields. Plausibility shields are used to show speakers' own attitude towards a proposition. Then, Attribution Shields attribute the degree of uncertainty toward a proposition to another party. From 61 plausibility shields uttered, "I think" was the most dominant hedging device uttered by the president. Specifically, it was uttered more frequently in the first interview (Data 1) than the second one (Data 2) .The president uttered this device 21 times in the first interview, and 14 times (including "I don't think") in the 
second one. It conveys that the president's degree of doubtful in the second term first presidential interview was less decrease.

Unlike Plausibility Shields, which were more frequently used in the first term-first presidential interview, Attribution Shields were more frequently uttered in the second one. From 81 Attribution Shields, 56 of them were uttered in second interview (Data 2). A closer look at the president's choice of words, "You know" and "If we" were the most favorite devices uttered by the president. 25 items for "You know" and 10 items for "If we". They do clarify that, in the second presidency term, in answering the questions, president Obama preferred filling the pause via uttering the Attribution Shields of "You know" to showing his doubtful via Plausibility ones. Whether or not it is only a matter of an introductory phrase to fill the sentence pause, we are going to discuss it in the second part.

Approximators, then, refer to hedging devices that affect the truth condition of the proposition. Sometimes, they even change the meaning of the proposition. They are manifested into Adaptors and Rounders. Adaptors can be regarded as modifiers to suit a non-prototypical situation, Rounders indicate the inexact preciseness of terms. In discussing the first subclass of Approximators, Adaptors, "Some"-"Some of" were the most dominant hedging device used both in the first and second interview. This fact shows the president's uncertainty to suit with non-prototypical conditions. To put it more specific, it can be clarified that, no matter what the questions were (politic or economic), the president had more intention to measure or judge a proposition via getting its class membership in a partial correctness.

It does clarify that politicians, specifically Barrack Obama as the best representative, are hard to say a definite proposition if the exact data is unavailable or if they are sure that their receivers will not find any difficulty in finding the meaning. What the researcher wants to say is that even the speaker.

Then, there was only 1 Rounder, "...or...", uttered in the first interview and 10 Rounders uttered in the second interview, which was dominated by "...or..." as well. They reveal that limiting the choice of items to convey a range of the unavailable exact data was his other way to ease the receivers catching the meaning and to solve his problem for not knowing the exact data.

Overall, comparing the first interview to the second one, no wonder if Adaptors and Rounders were more frequently uttered in the second interview than in the first one due to the economic topic. This is the very clear plausible reason for them to work in tandem with economic cases specifically to convey a range.

Towards the first and second presidential interview, Obama tried to follow his rhetoric with genuine diplomacy. Genuine, for the first interview, in the sense that president Obama has tended to tell a much different kind of story involving real, historical characters whose destinies are not foreordained. In his story, what happens is a matter of history: what human beings decide to do with their circumstances. Of course, an important part of how people make history is how they use words and symbols to represent circumstances and motives to themselves and to one another. This is why he has very carefully steered clear of phrases. Words matter, and this is why Obama makes a pointed rhetorical effort in the interview via hedging with Al Arabiya to isolate jihadism as a specific phenomenon that is unrepresentative of, and peripheral to, the Muslim world.

Also, he characterizes the problems of the Middle East not in terms of U.S. interests, but rather in diplomatic terms as a field of contention between a number of parties whose interests are legitimate but do not coincide. In other words, he doesn't view the Middle East through the narcissistic lens of a mythological war between good and evil whose outcome is inevitable. Instead, he represents the issues and conflicts of the Middle East as an ongoing story of competing interests. His words indicate not a belief in the inevitable victory of good over evil, but rather a belief in international politics: he argues that with attention, work, and diplomacy the competing interests and conflicting parties of the region can negotiate their differences without violence.

Genuine, for the second interview, in the sense of his words, despite indicating criticism, are presented via hedging to serve politeness. Also, to cover the unavailable exact data, he utters so many Approximators for protecting himself against any possible criticism if proved wrong later on. Above all, it is clarified that he likes to draw his receivers' attention to the intended meanings, just like when he said,

...the acknowledgment that if we're going to raise revenues that are sufficient to balance with the very tough cuts that we've already made and the further reforms in entitlements that I'm prepared to make, that we're going to have to see the rates on the top 2 percent go up. And we're not going to be able to get a deal without it... 
... You know, there's been a lot of talk that somehow we can raise $\$ 800$ billion or $\$ 1$ trillion worth of revenue just by closing loopholes and deductions, but a lot of your viewers understand that the only way to do that would be if you completely eliminated, for example, charitable deductions. Well, if you eliminated charitable deductions, that means every hospital and university and not-for-profit agency across the country would suddenly find themselves on the verge of collapse. So that's not a realistic option......).

These are only two of the other statements, which contain hedging, uttered to realize his receivers (the Republicans, CEOs and Americans of course) that it's all about how important for all offers to move beyond their opening positions and reach agreement on a comprehensive plan which avoids the fiscal cliff and puts the debt on a clear downward path relative to the economy.

The hedging devices in the second interview, overall, thus, do help the president to propose a rhetorical effort for strengthening how important to avert the so called "fiscal cliff". He, for examples, often uttered the hypothetical device of "if" to convince his receivers that lowering rates for the wealthy and sticks the middle class with the bill takes promise. Also, uttering the adverbs/adjectives devices - Approximators - to rhetorically convince his receivers the fact that until the Republicans in Congress are willing to get serious about asking the wealthiest to pay slightly higher tax rates, Americans won't be able to achieve a significant, balanced approach to reduce the deficit the nation need.

In essence, what Pyle stated in 1975 that 'hedging is able to stem from the inner conflict between intention and desire' (p.2) can be judged as a correct fact as being indirect is a mechanism for dealing with conflicting intentions and desires. The general form of the conflict is that the speaker wants to convey $X$ for some reasons and he does not want to convey $X$ for other reasons. By being indirect he can convey $X$ in one sense but not in another.

In short, the main reason behind using hedging as a rhetorical strategy is attributed to the struggle in attracting the receiver's attention to situation whereby he/she can understand the intended message. Hedging, thus, is a powerful strategy to stem from the inner conflict between intention and desire.

\section{Conclusion}

In analyzing hedging types, this study found that Adaptors and Rounders were more frequently uttered in the second interview than in the first one due to the economic topic. Considering the political and economical topics in both interviews, a line can be drawn: Politicians are not a good truth teller for considering the various devices uttered to serve hedging. The subject of this study dislikes direct answers in most of his political actions, specifically in the first interviews. It, thus, conveys a fact that conversational and discourse strategies including Grice's maxim's are rarely adhered to in spoken political discourse.

After analyzing the types, this study found various pragmatic functions, covering: devoiding the senders' involvement, requesting the receivers' involvement, avoiding direct criticism, mitigating claims, avoiding hurting others, protecting the sender against any possible criticism and expressing politeness.

Overall, five findings are formulated. The first one deals with the fact that there is no limit to the linguistic expressions that can be considered as hedging devices. Then, conversational and discourse strategies including Grice's maxim's are rarely adhered to in spoken political discourse. Thirdly, hedging is able to stem from the inner conflict between intention and desire. Fourthly, politicians hardly produces a sentence that is free of all kinds of indirectness, indetermination, approximation or vagueness. The last one, the main reason behind using hedging as a rhetorical strategy is attributed to the struggle in attracting the receiver's attention to the intended message.

\section{References}

Baena, E. \& Lacorte, M. 2002. Para entender la Pragmática. Ed. Gredos. BBC News. 2002. Text: Beirut Declaration. Retrieved January 12, 2009.

Brown, Penelope \& Steven C. Levinson 1987. Politeness-Some Universals in Lnaguage Usage. London: Cambridge University Press..

Canale, Michael. 1983. From communicative competence in communicative language in Richards and Schmidt (eds.). Language and Communication. London: longman, pp. 2-28.

Channell, J. 1994. Vague Language. Oxford: Oxford University Press. 
Clemen, G. 1997. The concept of hedging: Origins, approaches and definition, in R. Markkanen and H. Schro der (eds.), 1997.

Coates, J. 1996. Women Talk: Conversation between Women Friends. Cambridge: Blackwell.

Cullough. 2013. American Exceptionalism. Retrieved from http://www.filibustercartoons.com/usa.htm .

Cutting, J. 2002. Pragmatics and Discourse. London and New York: Routledge.

Froomkin, D. 2009. Washington. Post 1/27/2009. http://www.cggl.org/scripts/opinion.asp?id=263

Dimitrova, Daniela. 2012. The Relationship between Media and Politics in Post-Communist Bulgaria. Bulgaria: Iowa State University.

Denzin N. and Lincoln Y. (Eds.). 2000. Handbook of Qualitative Research. London: Sage.Publication Inc.

Fairclough, Norman. 1989. Language and Power Goldstein, E. Bruce. 2008. Cognitive Psychology: Connecting Mind, Research, and Everyday Experience, 2nd ed. Thomson.

Fokkema, Ibsch. 1998. Teori Sastra Abad Keduapuluh. Jakarta: PT. Gramedia.

Fraser, B. 2010. Hedging in Political Discourse: The Bush 2007 press conferences. In Okulska, Urszula \& Cap, Piotr (Eds.). Perspectives on Politics and Discourse, 36, 201-214. Amsterdam/ Philadelphia: John Benjamins Publishing Company.

Fraser, B. 2010. Pragmatics Competence: The Case of Hedging. In: Kalenbock, Mihatsch and Schneider (Eds.). New Approaches to Hedging. England: Emerald Group Publishing Limited.

Goody, N.E. 1996. Questions and Politeness. London: Cambridge University Press.

Grice, P., 1975. 'Speech Acts'. In: Cole, P. and Morgan. J. (eds) Logic and Conversation In Syntax and Semantics. New York: Academic Press. Reprinted in Studies in the Way of Words, ed. H. P. Grice, pp. 22-40. Cambridge, MA: Harvard University Press (1989).

Grundy, P. 2000. Doing Pragmatics. New York: Oxford University Press.

Hornby, A.S. 1974.Oxford Advanced Learners Dictionary of Current English. New York: Oxford University Press.

Hyland, K. 1998. Hedging in Scientific Research Articles. Amsterdam/Philadelphia: John Benjamins.

Hinkelman, Elizabeth. 1987. A Plan-Rased: Approach to Conv'ersational Implicature Computer Science Department. . New York: The University of Rochester Rochester.

Key, James P. 1997. Research Design in Occupational Education: Qualitative Research. Oklahoma: Oklahoma State University Press.

Lakoff, G. 1973. Hedges: a Study in Meaning Criteria and the Logic of Fuzzy Concept. Journal of Philosophical Logic 2. Dordrecht-Holland: D. Reidel Publishing Company.

Lakoff, G. 1972. Hedges: A study in meaning criteria and the logic of fuzzy concept, Papers from the Eighth Regional Meeting of the Chicago Linguistic Society , 183-228. Reprinted in Journal of Philosophical Logic.

Lincoln, Y.S \& E.G. Guba. 1985. Naturalistic Inquiry. London: Sage Publications.

Lister, Martin, Jon Dovey, Seith Giddings, Iain Grant and Kieran Kelly. 2003. New Media: a Critical Introduction. London and New York: Routledge.

MacLeod, S. 2009. Time to Test the Arab Peace Offer. Retrieved on January, 8, 2009.

Miles, Mathew \& A. Michael Huberman. 1994. Qualitative Data Analysis: An Expanded Source Book $\left(2^{\text {nd }}\right.$ edition). Thousand Oakes: Sage.

Murray, G. 2009. Narrative Inquiry: In Heigham, J. and Croker, R.A. (eds.). Qualitative Research in Applied Linguistics: A Practical In tropduction. New YoRK: Palgrave MacMillan.

Ospina, Sonia. 2004. Qualitative Research: Encyclopedia of Leadership. London: SAGE Publications.

Partington, A. 2003. The linguistics of political argument: The spin-doctor and the wolf-pack at the white house. New York: Routledge.

Pindi, M. \& Bloor, T. 1987. Playing Safe with Predictions: Hedging, Attribution and Conditions in Economic Forecasting. In: T. Bloor, and J.Norrish (Eds.) Written Language. CILT, 55-69.

Potempa, Phillip. 2008. President-Elect Barack Obama's speaking skills paved road to White House. NWI.COM.

Pyle, C. 1975. The Functions of Indirectness. Paper Read at N-WAVE IV Georgetown University. Quirk, R. (1978). Language and Tabu. New Society.

Richardson, John E. 2007. Analysing Newspapers: An Approach from Critical Discourse Analysis. Hampshire and New York: Plgrave MacMillan.

Riese, Hanne. N.d. Observation and interview as interconnected and mutually dependent parts of qualitative research. Seksjon for utdanningsvitenskap, Institutt for utdanning og Helse. Universitetet i Bergen.

Roggeveen, Sam. 2009. Obama's Dignity Agenda. Retrieved from http://www.lowyinterpreter.org/post/2009/01/28/Obamas-dignity-agenda.aspx

Sabrina, S. 2013. Politics: John Boehner To Obama On Fiscal Cliff: Act On Plan B Or Get 'Serious'. U.S: Huft Post. Retreived from http://www.huffingtonpost.com/2012/12/20/john-boehnerobama_n_2339940.html 
Salager- Meyer, F. 1994. Hedges and textual Communicative Function in Medical English Written Discourse. In English for Specific Purpose 13 (2) (149-170).

Salager- Meyer, F. 1997. I Think that perhaps you should: A Study of Hedges in Written Scientific Discourse. In T.Miller (ed), Functional Approaches to Written Text: Classroom Applications. Washington D.C. USIA. (105-118).

Sandell, R. 1977. Linguistics style and persuasion. London: Academic Press.

Siddiqui, Sabrina. 2012. John Boehner to Obama on Fiscal Cliff: Act on Plan B or Get 'Serious'. Retrieved from http://www.huffingtonpost.com/2012/12/20/john-boehner obama_n_2339940.html.

Simpson-Meyer, F. 2004. Discourse in the Professions: Perspectives from Corpus Linguistics Stylistic Features of Academic Speech: The Role of Formulaic Expressions. John Benjamins Publishing Company.

Taweel, Abeer Q., Saidat, Emad M. Rafayah, Hussein A., \& Saidat, Ahmad M. 2011. Hedging in Political Discourse. The Linguistics Journal. Volume 5 Issue 1. Ma'an, Jordan: Al Hussein Bin Talal University.

Thomas, David R. 2002. Qualitative Research Methods Data Gathering \&Data Analysis. University of Auckland: Health Research Methods Advisory Service Department of Community Health.

Titscher, Stefan, Michael Meyer, Ruth Wodak, Eva Vetter. 2000. Methods of Text and Discourse Analysis. London: Sage Publucations.

Traugott, Elizabeth Closs and Pratt, Mary Louise. 1980. Linguistics for students of literature. Florida: Harcourt brace javanovich, inc.

Vanderveken, D. n.d. Towards a Formal Pragmatics of Discourse.

Van Dijk, Teun A. 1997. What is Political Discourse Analysis?. In: Blommaert, ian \& Chris Bulcaen (Eds.). Political linguistics. (pp. 11-52). Amsterdam: Benjamins.

Wee, Lian-Hee and Winnie H.Y. Cheung. 2009. An animated and narrated glossary of terms used in Linguistics. Hongkong: Hong Kong Baptist University.

Yoav, S. 2008. Abbas calls on Obama to enact Arab peace plan as soon as he takes office". Haaretz. Associated Press.

Yule, G. 1996. Pragmatics. Oxford: University Press. 